\title{
Trades, Transport, or Construction
}

National Cancer Institute

\section{Source}

National Cancer Institute. Trades, Transport, or Construction. NCI Thesaurus. Code C148248.

Occupations that include tradesmen, laborers, or professional employed in the physical construction of the built environment and its infrastructure, as well as professional or vocational positions of employment that involve transportation or material moving. 